\title{
SOCIAL DIMENSION OF EUROPEAN UNION AND THE SITUATION OF THE LABOUR LAW IN THE MEMBER STATES: EVALUATION OF THE SPANISH EXPERIENCE
}

Núm. 1(2013), pp. 54-71.

Antonio Baylos ${ }^{1}$, Francisco Trillo².

Recibido: Junio, 2013

Aceptado: Septiembre, 2013

JEL Clasif: A13

\footnotetext{
${ }^{1}$ Labour Law and Social Security in the Castilla-La Mancha University (Spain): Antonio.Baylos@uclm.es

${ }^{2}$ Labour Law and Social Security in the Castilla-La Mancha University(Spain): FcoJose.Trillo@uclm.es
} 


\begin{abstract}
The EU decision to take into account only economical origin and discard the social one, adopting the Pact of Euro as the best -and only- way to get over the crisis, has the mistake to confuse origin and consequences. As known, the main content of the Pact of Euro is addressed to reduce public deficit. As a result of these policies, almost all EU-27 countries have been converting private debt in public debat, cutting public spending in Education, Health and Social Service and bailing out several banks, worsening crisis social causes. This idea, obviously, is expressed in another way, affirming that in order to maintain Social State is firstly necessary to control public deficit. But in fact, after five years of austerity measures, there are many doubts about sincerity of these (neoliberalism) policies.
\end{abstract}

KeyWords: Neoliberalism; euro; crisis; austerity; policies; financial markets; right to work; regulations of labour.

\title{
Resumen
}

La decisión de la UE de tener en cuenta sólo el origen económico, descartando el social, adoptando el Pacto del Euro como la mejor y única manera de superar la crisis, tiene el error de confundir el origen y sus consecuencias. Es sabido que el contenido principal del Pacto del Euro se dirige a reducir el déficit público. Como resultado de estas políticas, casi todos los países de la UE-27 han estado convirtiendo la deuda privada en debate público, reduciendo el gasto público en Educación, Salud y Servicios Sociales y con el rescate de varios bancos, con un empeoramiento de las causas sociales debido a la crisis. Esta idea, por supuesto, se expresa de otra manera, afirmando que con el fin de mantener el Estado social es una parte necesaria para controlar el déficit público. Pero, de hecho, después de cinco años de medidas de austeridad, hay muchas dudas acerca de la sinceridad de estas políticas (neoliberalismo).

Palabras Clave: Neoliberalismo; euro; crisis; austeridad; mercados financieros; políticas; derecho al trabajo; regulación laboral. 


\section{Crisis? What crisis}

Since 2008, the EU is living the so-called financial crisis, that is impacting in a different way depending on the Member State. We can distinguish two different groups of the EU Member States: a) Northern countries, leaded by Germany and France and b) Southern countries, known as PIIGS or more recently GIPSI countries, as a new category to refer countries in difficulties with their financing public debts. This situation among European countries provides some interesting information about the EU construction process but also regarding the origin of the crisis. Let`s examine some official arguments about the origin of the crisis.

Basically, the official version identifies crisis`s origin only with the deregulation of the financial-sector, reducing the analyses of the causes in the idea below: the crash of 2008 is based on the collapse of the subprime mortgages and the lack of financial market regulation.

These kinds of explanations are not satisfactory because do not answer the very important question about the reason of the massive indebtedness of workers and families that has been characterizing the last two decades. It is necessary then to explore others roots, social roots, as the causes of the massive indebtedness of the families. One of them could be identified in the wages development in the different European labour markets or, more in general, in the inequality evolution of the last decades.

Official information provided by European Commission about the situation of the EU-27 at-risk-of-poverty population indicates how, since 2003, the main reason of these rates of poverty has to be found in incomes distribution inequality especially affecting the peripheral European countries. In other words, massive families' indebtedness has turned an ordinary social condition because of wealth distribution inequality (Lettieri, 2011). It is thus possible to affirm that "work" has been losing it social and economical function as a "vehicle" that provides the condition of citizen, by means of progressive imposition of worse working conditions. Furthermore, these trends have become in to the principles of productive model not only in the EU but also in the USA, with several consequences in the labour relations consideration and regulation. 
Traditional relationship between worker and consumer has been broken as a result of the banking sector irruptions in the economy and of the so-called "financiarization" of the economy. So, in the last two decades, the only way to access to certain basic and fundamental rights, goods and services has not been through work, but via workers and families' indebtedness 3 . Therefore, regulations of labour markets in Europe, especially in this crisis, are not being related with social and economical worker's conditions but with macroeconomics necessities such as costs reduction in order to provide better competitiveness to enterprises (Krugman, 2012) or more recently as a way to reduce public deficit.

This kind of view, not only economical, would allow analyzing the situation in order to select the best measures to tackle the crisis, concretely, in the field of labour relations. Therefore, it could be very useful to distinguish the origin of the crisis and the consequences of the measures to tackle it. European model to get over the crisis is the best example to understand the importance to distinguish origin from consequences.

The EU decision to take into account only economical origin and discard the social one, adopting the Pact of Euro as the best -and only- way to get over the crisis, has the mistake to confuse origin and consequences. As known, the main content of the Pact of Euro is addressed to reduce public deficit. As a result of these policies, almost all EU-27 countries have been converting private debt in public debt 4 , cutting public spending in Education, Health and Social Service and bailing out several banks, worsening crisis social causes.

As informed recently $\mathrm{OECD}^{5}$, EU unconcern about incomes distribution rising inequality due to working regulation reforms is producing more inequality, apart from disfigure national labour regulations, homogenizing labour relations rules in the way of neoliberalism and colonialism (Hudson \& Sommers, 2011).

\footnotetext{
3 In particular, it has been the situation for Spanish families to access to the housing right in the last two decades.

4 "Before the crisis Spain was well within the euro zone's fiscal rules. Even now its government debt, at around 70\% of GDP, is lower than Germany's. As in Ireland, the origins of Spain's debt problems are private, not public. A debt binge by Spanish households and firms fuelled a property bubble and left the country enormously in hock to foreigners. After adjusting for all the foreign assets they own, Spain's households, firms and government collectively owe foreigners almost $€ 1$ trillion ( $\$ 1.25$ trillion), or more than $90 \%$ of GDP. That is on a par with crisis-hit Greece, Ireland and Portugal, and far higher than in any other big rich economy. Spain's banks were the conduit for this private borrowing binge, and are being hit hardest by the bust". In http://www.economist.com/node/21556238.
}

5 OECD, Divided we stand. Why inequality keeps rising? OECD Publishing, 2011. 


\section{Evaluating austerity policies and Labor Law: official discourses.}

Since According to the European Commission and the institutions regulating the financial markets, such as the ECB and the IMF, economic measures aimed to reduce public deficit should be accompanied by government action to impose deep "structural reforms" of national legislations, which meant carrying out a series of reforms relating to labour relations, the social security systems and collective bargaining, with the express purpose of creating and/or maintaining employment rates. In other words, while State macroeconomic action should tend towards reducing public deficit, and hence the contraction of the public sector, efforts to maintain and create jobs have been restricted to revising the regulation of labour relations and social protection systems. Two main lines of action have therefore emerged.

The first relates to the "inevitable" nature of austerity measures and public deficit reduction as the only way to tackle the crisis and to achieve economic recovery. The political and economical debate has therefore moved away from issues such as changing the production model and the reforms needed in the field of business with a view to strengthening economic activity, that over recent decades has been almost entirely based on the real estate sector, with a spiral of speculation and rising prices in residential property. Absolving economic and business actors of their responsibilities in this way, by means of the implementation of policies to reduce public spending, has been recently evaluated and criticized as having depressive effects on the so-called real economy (Guajardo, Leigh \& Pescatori, 2011).

The second line of action, which reflects the first, is closely related to the reforms carried out in labour relations, led by the arguable principle that jobs can only be created or maintained by reducing legal and political employment guarantees and reducing average pay standards and working conditions, setting job creation against robust employment rights. This view, which is nothing new in several European countries, has not been shown to be correct, either in the current crisis or in previous crisis, such as those in the 1980 s and 1990s. Nevertheless, during 2009-2012, there has been an intense process of reforms, from both qualitative and quantitative points of view, which see employment rights as the main cause of legislative rigidity and hence job destruction. 
From this point of view, labour law is responsible of job destruction because of its rigidity and its intention to recognize working rights in a continuous change business world. So, the proposals to get over the unemployment crisis have taken the rules of labor relations, at the same time, as the main problem and the great solution, forgetting that, in others times, labor law rigidity brought to the highest employment rates ${ }^{6}$. Anyway, we do not pretend in this moment combat this kind of futile arguments, but we are interested in demonstrate how the official version is based to blame some behaviors resumed in the idea that some countries have lived "beyond their possibilities", also in economical, social and labour rights. That's why these countries have now to reduce living and working conditions as a remedy against the crisis. Even if this kind of remedy could cause very strong inequalities among the EU Member States affecting the main European principles and values as social cohesion, solidarity or equality.

As it will be seen in the next paragraph with the presentation of spanish case, Labour Law is being hurting in his bases, turned into a group of rules aimed, on one hand, to solve macroeconomics problems such as international enterprises competitiveness or public deficit reduction and, on the other hand, to improve employment rates. So, new labour law do not take worker as subject to protect, hence intended as a merely production factor.

In this sense, ILO has recently pointed out that real wages in the developed countries, especially in Europe, has remained far below pre-crisis levels7:

"Monthly average wages adjusted for inflation-known as real average wages- grew globally by 1.2 per cent in 2011, down from 2.1 per cent in 2010 and 3 per cent in 2007. Average labour productivity in developed economies increased more than twice while real monthly wages remained flat. The global trend has resulted in a change in the distribution of national income, with the workers' share decreasing while capital income shares increase in a majority of countries. A decrease in the labour share is affecting household consumption and can thus create shortfalls in the aggregate

\footnotetext{
${ }^{6}$ For instant, in Spain from 1997 to 2007 was the period in which the highest employment rates were achieved. Maybe, this situation finds explanation in the relation between Gross Domestic Product and employment, as has been pointed recently by ILO, Global Wage Report 2012/2013. Wages and equitable growth. International Labour Office, Geneva, 2012, p. 16.

7 ILO, Global Wage Report 2012/2013. Wages and equitable growth. International Labour Office, Geneva, 2012.
} 
demand. These shortfalls in some countries have been compensated by increasing their net exports, but not all countries can run a current account surplus at the same time. Hence, a strategy of cutting unit labour costs, a frequent policy recommendation for crisis countries with current account deficits, may run the risk of depressing domestic consumption more than it increases exports. If competitive wage cuts are pursued simultaneously in a large number of countries, this may lead to a "race to the bottom" in labour shares, shrinking aggregate demand”.

On the other hand, structural labour reforms have taken employment as a main goal according to a particular way to understand flexicurity policies. So, many labour reforms are going in depth in numerical flexibility, especially in economic dismissal, blaming stability of employment as responsible of job destruction without assure social protection in the transitions from unemployment to employment and with a scarce care about active employment policies. In this way, flexicurity policies appear as a wish in which employers are the only actors to carry out these creating jobs strategies, without a presence of public authorities in the determination of the policies or in control in their putting into operation.

Beyond this paradoxical situation, this kind of arguments has as immediate result working-class fragmentation because unemployed workers tend to blame for their situation employed workers and so on. So, workers representative subject, trade union, is in a very difficult position to accomplish his term of office trying to avoid his presence as part of the solution, otherwise as a part of the problem. Therefore, last reforms have punished in a strong way trade unions, reducing their abilities to represent economical and social workers interests, especially in collective bargaining by means of unapplied collective agreements by employer decision.

At last, these reforms, apart from modifying national labour laws in an dated and archaic way, have a hard impact on economic inefficiency and on wealth incomes inequality distribution between work and capital shares and among European Member States, without achieve either better employment rates or economic recovery. 


\section{Re-directing Labour Law to Master and Servant}

\section{Law.}

Since May of 2010, Spanish Labour Law is suffering very deep structural reforms that are transforming it. It means that financial crisis is creating a crisis in Labour Law, at least in two different grounds: a) on the processes of Labour Law creation and institutional framework and b) in the Labour Law itself.

a) Financial crisis is causing a "crisis" on the processes of Labour Law creation and institutional framework

In the last three years, in all fields but especially in labour relations, the usual way to create law is being the exceptional regulation -Royal Decree-Law-with a very negative impact in Parliament activity. This is because political debates are taking place only in Ministries Conceal leaving to the Spanish Parliament the only function to ratify exceptional regulation (see Legislative Annex). Furthermore, the majority in Parliament of Partido Popular denies any possibility to discuss or modify exceptional regulation.

Nevertheless RD-Law 10/2010 and RD-Law 3/2012 were adopted by both Governments -Socialist Party and Popular Party Government-, this decision and its contents were decided beyond spanish frameworks by ECB, preventing public debate about the reform`s goals and means to achieve them.

In the field of Labour Law, legal authoritarianism imposed by Government means also a control of collective autonomy as main resource of labour law creation, affecting, basically, binding efficacy of statutory collective agreements and their ultra-activity. Law 3/2012 provides a complete substitute of the collective bargaining spaces by legal commitments. In other words, imperative rules contained in the last reforms cannot modify by collective bargaining. This anti-collective labour law`s usage is a particular element of spanish center-right government, missing dated Francoist`s Labour Law, because in practice, law selects bargaining levels depending on the subjects. Derogation of company collective agreement doesn't allow a different regulation by sectoral bargaining and tries to substitute partners agreement with a mandatory arbitration. In the 
same sense, a compulsory rule about preference of company collective agreement versus sectoral collective agreements has been introduced.

Overall, Law 3/2012 exalts unilateral employer decision in working regulation as a principle of new labour law, impacting information, consultation and negotiation rights. Hence, we can say that new labour law is characterized by a strong legal and employer authoritarianism. Therefore, presence of trade unions disturbs actual legal action because they are being almost the only actors that are tackling crisis in other way, taking into account social effects of the measures to get over the crisis.

\section{b) Financial crisis is causing a "crisis" in the Labour Law itself}

As we have seen, crisis is carrying out new processes of Labour Law creation that are transforming the Labor Law itself. Of labour relations "structural reforms" advocated by the European Union, we would stress the areas in which there has been noticeable change: contracts, internal flexibility and redundancy for economic, technical, organizational and productive reasons. The contents of these reforms are analyzed below.

\section{Contracts:}

Evaluating the conditions of contracts, reforms introduced over the last two years followed an intense debate on one of the peculiarities of the Spanish labour market: the high rate of temporary employment. This atypical feature has been in place since the end of the 1980s, reached a rate of $34.8 \%$ in 2006. This weakness of the Spanish market is one of the factors explaining the extremely rapid and widespread destruction of jobs seen during the first two years of the economic and financial crisis. Therefore, during the first stage of reforms, the imposition of certain legal controls of temporary contracts was promoted, adopting an approach which was somewhat traditional in Spanish legislation and which had been reinforced before the crisis, in the reform of 2006, the result of dialogue between the social actors. However, there was a second stage during which this trend was reversed. 
Law 3/2012 (Article 4) has implemented a new type of contract called non-fix contract supporting entrepreneurs -contrato indefindo de apoyo a los emprendedores-, which main feature is the possibility to extend trial period, in any case, up to one year, terminating labor relation without justified reasons or compensation for dismissal. This kind of contract can be used in companies until 50 workers, 99,23\% of spanish companies as inform us Law's Preamble. In other words, employers could use non-fix contract supporting entrepreneurs to assume workers, as fix and non-fix within first year of contract`s life. So, causality principle in contracts is in risk, breaking guarantees of right to work as if there was not a specific cause, employer is obligated to use a nonfix contract, but also regarding labour rights guarantees in dismissal, because non-fix contract supporting entrepreneurs allows employers not to justify labor relation`s termination reasons.

\section{Internal flexibility:}

Internal flexibility is a crucial instrument in terms of reducing unemployment and increasing productivity in the Spanish economy, as stated in Law 3/2012. This evaluation and conclusion reached by the legislator in 2012 is not very different from the conclusion that had been reached by the social partners by means of social dialogue in the successive Interconfederal collective bargaining agreements that have been taking place within the legal system since 1997. The establishment and development of a certain model of internal flexibility can bring beneficial effects capable of meeting needs both of employers and of workers, making it possible to quickly adapt working conditions, working times and wages to the changing demands of the markets in which a particular company is operating, as a result avoiding external flexibility, temporary contracts and redundancy, as mechanisms for adjustments to certain company needs.

However, Law 3/2012 differs from the Interconfederal collective bargaining agreements in terms of its view of where internal flexibility should be introduced. While Interconfederal agreements have considered that this kind of flexible regulation should take place within the sectoral collective bargaining context, introducing a series of rules to govern the whole production industry according to the internal flexibility needs of the sector, Law 3/2012 has left the decision about the introduction of internal flexibility to 
the employer's will, via company-level agreements to be reached with workers' representatives at that level, taking this role away from collective bargaining. The reform, therefore, means a general absence of application, at company level, of provisions laid down at sectoral level.

Generally speaking, this internal flexibility model produces a series of effects which have been criticized for their impact on labour relations governance via collective bargaining. This model involves the progressive establishment of working conditions at the companies level or workplaces, which prevents the use of internal flexibility measures from being extended to the production sector as a whole and reduces the capacity of collective parties to regulate working conditions, with a particular negative impact on job stability, health and safety at work and the reconciliation of family, personal and working lives.

Dismissal for economic, technical, organizational or productive reasons:

The final area of great importance amongst the structural legal reforms regarding labour relations is that related to dismissal for economic, technical, organizational or productive reasons.

The reasons for the dismissal reform are explained in the Preamble of Law 3/2012, with a key objective: to rectify dysfunctionality over recent years of many terminations of indefinite contracts, which in reality are based on economic or productive reasons, being classed as unjustified disciplinary dismissals. This situation, which Law 3/2012 is intended to rectify, originates in 2002 labour market reform that amongst other things modified the effects of disciplinary grounds dismissal declared unjustified (Article 56(2) of the Workers' Statute). Legislator introduced the possibility for the employer to acknowledge in the same formal act of dismissal on disciplinary grounds the unjustified nature of that dismissal, providing the worker with a relevant compensation, and thereby avoiding salaries from the time of dismissal to the time when the court declares it unjustified (procedural salaries). Beyond the specific evaluation of this type of dismissal governed from the outside, that reform has led to a phenomenon known as 
"express" dismissal on disciplinary grounds, in which employers can use this type of dismissal irrespective of the true reason for it.

This objective of the 2012 reform of reinforcing the reasons for the termination of employment contracts, ensuring that the true reasons for the termination are given, raises the issue of the conduct of companies prior to the reform with regard to the choice of the type of dismissal. Far from seeking a legislative means to ensure that the classification of dismissal reflects the true reason for the dismissal, the legislator ignored this fraudulent behavior in 2012, insisting on the legal fiction that companies are free to dismiss workers in an unjustified or groundless manner, provided that the worker receives their corresponding compensation, reducing the act of dismissal to a mere economic transaction and absolving the company of any responsibility for their illegal action.

The responsibility of companies has been further reduced in Law 3/2012, which interprets the illegal conduct of employers as merely a dysfunction of employment legislation, which must therefore be corrected in order to provide greater certainty to workers, employers and courts in their judicial control function.

This legislative option can disguise the fraud committed by employers over recent years in relation to dismissal, the true motivation of which has been the employer inconvenience to have their dismissal decision controlled. It should be noted that in application of Article 56(2) of the Workers' Statute, express dismissal on disciplinary grounds (unjustified), was not the cheapest option in terms of the cost of compensation, despite the saving in procedural salaries, but rather the quickest, by avoiding dismissal judicial control within the practice.

In regards to the instruments provided by the legislator to promote greater certainty to workers, employers and courts, we would draw the attention to an important aspect that has had the direct result of persuading employers to replace the use of dismissal on disciplinary grounds with that of objective dismissal.

This aspect relates to the new wording of the economic, technical, organizational or productive reasons for dismissal which, a priori, considerably increases employers' 
ability to use dismissal as a further organizational strategy in order to improve their competitive position in the market or better respond to the requirements of demand, overshadowing and contradicting the 2010 and 2012 legislation regarding internal flexibility as a mechanism for maintaining and creating jobs.

Finally, 2012 labor reform has implemented economical dismissal in public sector as the only employment adjustment mechanism. Royal Decree 1483/2012 has developed in these points Law 3/2012 contents, creating a very strong relationship between public deficit reduction and civil servant dismissal. In other words, Law 3/2012 and Royal Decree 1483/2012 have authorized to dismiss civil servant when: a) there was an unbalanced budget in that public administration and b) the budget has been cut in $5 \%$, with respect to previous year, or in $7 \%$, with respect to the previous two years

\section{An overall view of actual spanish Labour Law.}

Spanish labor relations are developing in a continuous deterioration of the rights framework. Law 3/2012 has emphasized the most negatives and authoritarianism aspects of its predecessor RD-Law 3/2012. Last developed rules, such as RD $1483 / 2012,29^{\text {th }}$ October, Regulation of collective dismissal, exasperate attacks against work and its guarantees, hence it will be necessary a severe corrections by the jurisdictional via in order to make it compatible with spanish legal system.

If we evaluate the effects of last labor reform, this is causing a real cataclysm in Spanish employment relations. Employment is falling down and there are always more people that are losing it. Since second semester of 2010 with the first reformist measures and 4,5 million unemployed people, employment situation is getting worse and worse, with 5 million unemployed persons at the end of 2011 and 5.780.000 in the last part of 2012 (25\% of working population). These unemployed rates were registered in the USA in 1929, or in Weimar`s Germany in the 30`s of last century. Labor reforms have contributed to increase unemployment. Moreover, this employment situation is completed with a social consumption contraction and an extended wages reduction. 
One of the most important elements of this situation regarding collective bargaining. Collective bargaining coverage rate was high in the previous period of the crisis -almost 12 million workers in 2008; 11,5 in 2009 and 10,8 million in 2010-. Since labor reforms, collective bargaining rates are rapidly decreasing (55\% in 2011 and 40\% in 2012). That is, there isn't an alteration in collective bargaining structure, otherwise is completely paralyzed. In public sector, collective bargaining is totally blocked with continuous attacks to civil servants working conditions as a consequence of a wide reduction process of collective rights such as consultation or negotiation rights.

Furthermore, 2012 labor reform is being questioned by trade unions. CCOO and UGT placed a complaint to ILO on the ground of violation of 98 and 87 ILO Conventions. This situation obliges ILO to gaze the EU as a territory where there are severe violations of Universal Rights recognized in ILO Declaration. It provoked a reaction in the Partido Socialista and Izquierda Plural who presented an unconstitutionality action against Law 3/2012, which was accepted by Constitutional Court in $30^{\text {th }}$ October 2012. Most important contents of this unconstitutionality action are related with violation of collective autonomy constitutional principle and right to work.

In respect to autonomy constitutional principle, appellants submitted unconstitutional many parts of Law 3/2012 regard collective bargaining such as usage of mandatory arbitration in that cases in which there is no agreement to disapply sectoral collective agreement, or theft of decisive subjects from collective bargaining, or an unilaterally principle imposed by legal reform in that situations in which employers need a productive reorganization or, in brief, prohibition to regulate compulsory retirement in collective bargaining as an employment policy.

In the field of constitutional guarantees of right to work, Socialist Party and Plural Left's deputies argued that trial period in non-fix contract supporting entrepreneurs -at least, one year- with free termination of labor relation (no justification, no compensation), infringes right to work that implies the right to not to be fired without justified reason, as an individual content of right to work. Furthermore, appellants argued that Law 3/2012 violates 158 ILO Convention, ratified by Spain in 1985, and 
Article 30 of the European Charter of Fundamental Rights, which has the same legal force than the EU Treaties. By the same token, appellants intended that virtual disappearance of causality, reasonability and proportionality principles on economical dismissal, collective, plural and individual, prevents within the practice a real judicial control, as an essential content of right to work (Article 35 Spanish Constitution). Together with this, appellants argued that disappearance of procedural salaries in cases of unfair dismissal when employer opting for compensation, hence punishing readmission option and rewarding job destruction, is discriminatory. As well, exclusion in public sector of suspension or reduction of working hours as an employment adjustment mechanism, in which only will be possible usage of dismissal like employment adjustment mechanism.

Probably, youth workers and women are suffering especially unemployment crisis with a very important increase of women searching of a job out of household, being their working time superior than men. In this sense, the worst effect of the crisis is being that gender equality is not a goal in political agenda yet and reconciliation rights are being affecting by a recession as a result of carrying out 2012 labor reform (Rodríguez Fernández, 2012).

\section{Epilogue: in search of European citizens` equality.}

Anti-crisis measures adopted by the moment are merely addressed to public deficit reduction as inevitable and only mean to get over the crisis and recovery economy. Maybe, it`s a solution for debt crisis, but public deficit isn`t the main problem of this crisis, as seen in the introductory part of this article. Furthermore, solving only debt crisis will produce a deepening in the actual crisis. The EU policies should attend social origins of 2008 crash. Does have the EU instruments to remove social origins of the crisis? YES. Which are they, then?

Before to answer these crucial questions, it is very important to identify and reach an agreement about main causes of crisis. It doesn't mean to forget reducing public 
deficit. It could be very useful to recover the so called fiscal abyss in the USA, as a recent example.

Financial markets have partially recovered the confidence of whole world economy when public deficit strategies in the USA will be based in increase revenues, maintaining social and welfare benefits for their population in order to avoid an economic recession. In other words, even financial markets are conscious that certain policies only based on cutting spending will bring to reinforcement the actual Great Recession. Therefore, the solution of the debate on revenues or spending as a strategy to get over the crisis is crucial, because it will mean to take into account a social point of view, hence social roots`crisis.

Reduce public deficit via revenues means to maintain Social State, above all if revenues are distributed in a proportionality way. Lastly, address revenues via imply be worried about a society project in which goals as public deficit and citizen`s equality are balanced. This position seems the Obama's one.

Generally speaking, it is possible to affirm the EU is no worried about a social project, because actual political positions seem to gaze to cutting spending as the only path to get over the crisis, even if that means to demolish Social State (and the European social model). This idea, obviously, is expressed in another way, affirming that in order to maintain Social State is firstly necessary to control public deficit. But in fact, after five years of austerity measures, there are many doubts about sincerity of these (neoliberalism) policies.

Furthermore, austerity policies are violating that main principles and rules of European legal system that, in our opinion, are part of the solution of the crisis. These principles and rules regard certain policies that consented, for decades, a relative peaceful coexistence in the EU.

We stand out in first place principle that affirm "in defining and implementing its policies and activities, the Union shall take into account requirements linked to the promotion of a high level of employment, the guarantee of adequate social protection, the fight against social exclusion, and a high level of education, training and protection 
of human health" (Article 9 Treaty on the Functioning of the European Union). In other words, even policies on public deficit reduction must take into account the goal of employment, equality and social protection. Failing that, the EU will be refusing its social characterization returning back to the origins of Economic European Community, provoking a re-nationalization process within the EU.

Secondly, article 9 Treaty on European Union provides that "in all its activities, the Union shall observe the principle of the equality of its citizens, who shall receive equal attention from its institutions, bodies, offices and agencies. Every national of a Member State shall be a citizen of the Union. Citizenship of the Union shall be additional to and not replace national citizenship". Actual inequality and risk of poverty rates among the EU Member States point out how not every national of Member States are receiving the same treatment in anti-crisis measures application, blaming some countries of their situation. 


\section{Referencias Bibliográficas}

Below is some statistical information about european and spanish situation:

- Relative median at-risk-of-poverty gap 2010, (\%): $\underline{\text { http://epp.eurostat.ec.europa.eu/statistics_explained/index.php?title=File:Relativ }}$ e_median_at-risk-ofpoverty_gap, 2010_(\%25).png\&filetimestamp=20121114142611\#file

- LABOUR FORCE SURVEY (Unemployed persons, by gender): http://epp.eurostat.ec.europa.eu/tgm/table.do?tab=table\&init=1\&language=en\&p code $=$ tsdec $450 \&$ plugin $=1$.

- LABOR FORCE SURVEY (Unemployment rates, by age): http://epp.eurostat.ec.europa.eu/tgm/table.do?tab=table\&init=1\&language=en\&p $\underline{\text { code }=\text { tsdec } 460 \& \text { plugin }=1}$.

- LABOR FORCE SURVEY (Unemployment persons, by gender and length of time job-seeking):

http://epp.eurostat.ec.europa.eu/tgm/table.do?tab=table\&init=1\&language=en\&p $\underline{\text { code }=\text { tgs } 00053 \& \text { plugin }=1}$.

- LABOR FORCE SURVEY (Workforce contract type): http://epp.eurostat.ec.europa.eu/tgm/table.do?tab=table\&init=1\&language=en\&p code $=$ tps $00073 \&$ plugin $=1$.

- UNEMPLOYMENT BENEFITS (Initial registrations of tax benefit recipients, by function):

http://epp.eurostat.ec.europa.eu/tgm/refreshTableAction.do?tab=table\&plugin=1 $\underline{\text { \&pcode }}=\mathrm{tps} 00106 \&$ language $=\mathrm{en}$. 